\title{
Accumulation of Macro- and Micronutrients and Nitrogen Demand-supply Relationship of 'Gala'/'Malling 26' Apple Trees Grown in Sand Culture
}

\author{
Lailiang Cheng ${ }^{1}$ and Richard Raba \\ Department of Horticulture, Cornell University, Ithaca, NY 14853
}

\begin{abstract}
Additional Index words. Dry matter, harvest index, leaf area development, Malus $\times$ domestica, uptake, reserve N
Abstract. Six-year-old 'Gala'/'Malling26' ('M.26') apple (Malus $\times$ domestica Borkh.) trees grown in sand culture were provided with a total of $30 \mathrm{~g}$ of $\mathrm{N}$ per tree as enriched ${ }^{15} \mathrm{~N}-\mathrm{NH}_{4} \mathrm{NO}_{3}$ in Hoagland's solution via fertigation to determine the magnitude and seasonal patterns of accumulation of macro- and micronutrients and the demandsupply relationship of $\mathrm{N}$. Crop load was adjusted to $8.2 \mathrm{fruit} / \mathrm{cm}^{2}$ trunk cross-sectional area, at king fruit diameter of $10 \mathrm{~mm}$ by hand-thinning. At each of seven key developmental stages throughout one annual growth cycle, four trees were excavated and destructively sampled for complete nutrient analysis. Nutrient concentrations in leaves and fruit fell within the recommended optimal range, and the fruit yield was $18.8 \mathrm{~kg} /$ tree (equivalent to $52.45 \mathrm{t} \cdot \mathrm{ha}^{-1}$ ) with an average fruit weight of $181 \mathrm{~g}$. The net accumulation of $\mathrm{N}, \mathrm{P}, \mathrm{K}, \mathrm{Ca}, \mathrm{Mg}$, and $\mathrm{S}$ from budbreak to fruit harvest was 19.8, 3.3, 36.0, 14.2, 4.4, and 1.6 g/tree, respectively, and that for $\mathrm{B}, \mathrm{Zn}, \mathrm{Cu}, \mathrm{Mn}$, and $\mathrm{Fe}$ was 93.6, 60.9, 46.5, 184.8, and 148.7 $\mathrm{mg} /$ tree, respectively. Nutrient accumulation by new growth (fruit plus shoots and leaves) accounted for over $90 \%$ of the net gain for $\mathrm{N}, \mathrm{P}, \mathrm{K}, \mathrm{Mg}, \mathrm{S}$, and $\mathrm{B}$ in the whole tree and a large proportion of the net gain for $\mathrm{Ca}, \mathrm{Zn}, \mathrm{Mn}$, and $\mathrm{Fe}$ (from $58.1 \%$ for $\mathrm{Zn}$ to $\mathbf{8 7 . 2 \%}$ of $\mathrm{Fe}$ ) from budbreak to fruit harvest. Differential nutrient accumulation patterns were found in shoots and leaves and fruit. The most rapid accumulation of all nutrients in shoots and leaves took place during active shoot growth from bloom to the end of shoot growth. The accumulation pattern of most nutrients corresponded well with the accumulation of dry matter, with continued accumulation observed only in total Ca and Mn in shoots and leaves after the end of shoot growth. Nutrient accumulation in fruit largely followed its dry matter accumulation, and a large proportion of the nutrient accumulation (from $58.1 \%$ for $\mathrm{Zn}$ to $77.4 \%$ of $\mathrm{K}$ ) occurred from the end of shoot growth to fruit harvest. At harvest, fruit contained more P, K, B, and Fe, whereas shoots and leaves had more $\mathrm{N}, \mathrm{Ca}, \mathrm{Mg}, \mathrm{S}, \mathrm{Zn}$, and $\mathrm{Mn}$. Most of the $\mathrm{N}$ demand by new growth at bloom was provided by tree reserve $\mathrm{N}$. Remobilization of $\mathrm{N}$ from perennial parts of the tree was found to support rapid fruit expansion from the end of shoot growth to fruit harvest. The most rapid uptake from current season's $\mathrm{N}$ supply occurred from bloom to the end of shoot growth, corresponding to the highest tree $\mathrm{N}$ demand. At harvest, $62.4 \%$ of the total $\mathrm{N}$ in new growth was in shoots and leaves, with the balance in fruit. Reserve $\mathrm{N}$ and current season's $\mathrm{N}$ uptake each contributed about $50 \%$ to the total $\mathbf{N}$ in the whole tree at harvest.
\end{abstract}

Nutrient management plays a more important role in ensuring good tree growth, cropping, and fruit quality for apple trees on dwarfing rootstocks in high-density plantings than for those on vigorous rootstocks because dwarf apple trees crop earlier and have higher yield and smaller root systems. With the development of leaf nutrient analysis and its wide adoption for diagnosis of tree nutrient status (Bould, 1966), fertilization practices in orchards are now routinely adjusted by comparing leaf analysis results against the known optimal range of leaf nutrient concentrations. However, effective nutrient management for these dwarf trees still requires a good understanding of their nutrient demand in terms of amount and timing because the optimal leaf nutrient concentrations do not reflect the actual amount and timing of tree nutrient requirements.

Received for publication 16 Oct. 2008. Accepted for publication 8 Dec. 2008 This work was primarily supported by a generous gift from Dr. David Zimerman (Cornell Pomology Ph.D., 1954). Additional support was provided by the New York Apple Research and Development Program. The 'Gala' trees used in this study were generously donated by Van Well Nursery (Wenatchee, WA).

We thank Andrea Mason, Louise Gray, Scott Henning, and the Cornell Orchard crew for technical assistance, and Dr. Ian Merwin for critical reading of the manuscript

${ }^{1}$ Corresponding author. E-mail: LC89@Cornell.edu.
Biomass determination via sequential tree excavation, coupled with nutrient analyses of each tissue type, appears to be the only reliable way to obtain the amounts and seasonal patterns of nutrient uptake (Weinbaum et al., 2001). Due to the difficulty associated with destructive sampling of entire trees at multiple times during the annual cycle of tree growth and development, the actual demand of dwarf apple trees for all macro- and micronutrients in terms of timing and amount has not been examined in detail. Van Slyke et al. (1905) first estimated the annual utilization of $\mathrm{N}, \mathrm{P}, \mathrm{K}, \mathrm{Ca}$, and $\mathrm{Mg}$ by mature 'Rhode Island Greening' and 'Baldwin' apple trees (presumably on seedling rootstocks) by determining the amount of macronutrients in fruit, leaves, and new wood. Recognizing that some nutrients are remobilized from woody perennial structural parts to support new growth, Magness and Regeimbal (1938) and Batjer et al. (1952) estimated the annual nutrient requirements of standard mature 'Delicious' apple trees by calculating the amount of each nutrient in shoots and leaves, fruit, and the new growth of woody perennial organs based on the nutrient concentration in each tissue and the proportion that was not remobilized, via subsampling coupled with nondestructive biomass estimation. In an attempt to develop a nutrient budget for commercial apple orchards in New Zealand, Haynes and 
Goh (1980) estimated via subsampling and nondestructive estimation of tree biomass that the total amounts of $\mathrm{N}, \mathrm{P}, \mathrm{K}$, $\mathrm{Ca}, \mathrm{Mg}, \mathrm{S}$, and $\mathrm{Cl}$ in 14-year-old 'Golden Delicious' on 'Northern Spy' rootstocks at 500 trees/ha were 121.2, 19.5, $196.4,162.4,21.9,15.4$, and $45.3 \mathrm{~kg} \cdot \mathrm{ha}^{-1}$. The annual requirements for these nutrients were not provided in the article, but are expected to be lower as the total content for each nutrient includes that accumulated from previous years. The early estimates on nutrient requirements (Batjer et al., 1952; Magness and Regeimbal, 1938; Van Slyke et al., 1905) may not be applicable to apple trees on dwarfing rootstocks in commercial orchards today because the trees used in these experiments most likely had a much larger proportion of structural wood and lower yield. In addition, the temporal patterns of nutrient requirements over the entire annual growth and developmental cycle were not addressed in any of these studies.

The application of ${ }^{15} \mathrm{~N}$-labeled $\mathrm{N}$ fertilizers, combined with destructive sampling of entire trees, has been used to quantify the uptake, partitioning, and internal cycling of fertilizer $\mathrm{N}$ in field-grown apple (Khemira et al., 1998; Neilsen et al., 2001), pear [Pyrus communis L. (Sanchez et al., 1991, 1992)], almond [Prunus amygdalus Batsch (Weinbaum et al., 1984, 1987)], peach [Prunus persica L. (Rosecrance et al., 1998)], and walnut [Juglans regia L. (Weinbaum and Kessel, 1998)]. These studies have provided valuable information for understanding tree $\mathrm{N}$ dynamics and optimizing $\mathrm{N}$ fertilization in orchards. However, because there are three sources of $\mathrm{N}$ supply to the new growth of field-grown trees (reserve $\mathrm{N}$, soil $\mathrm{N}$, and fertilizer $\mathrm{N}$ ), and only the fertilizer $\mathrm{N}$ is labeled with ${ }^{15} \mathrm{~N}$, the contribution of reserve $\mathrm{N}$ to total tree $\mathrm{N}$ economy during tree growth and development can only be estimated by assuming that the uptake of ${ }^{15} \mathrm{~N}$-fertilizer occurs entirely during the first year of application. This assumption may hold reasonably well on light-textured soils, but in heavy soils, some of the ${ }^{15} \mathrm{~N}$-fertilizers may be tied up by soil microbes and then released in subsequent years. Secondly, due to the difficulty associated with recovering the entire root system of field-grown trees, it is likely that the amount of $\mathrm{N}$ in root systems has been underestimated in these studies. Finally, because N was the only focus in these studies, other macronutrients and micronutrients were not examined.

An alternative to using field-grown trees for determining nutrient requirements is to grow apple trees in a sand culture to achieve optimal tree nutrient status, high yield, and good quality so that the amount of nutrients accumulated by these trees can be interpreted as nutrient requirements. The sand culture system eliminates competition for nutrients between any adjacent trees in the field in high-density plantings and allows good control of all the nutrients and better recovery of the entire root system at excavation. In addition, because the supply of $\mathrm{N}$ from the sand is negligible, there are only two sources of $\mathrm{N}$ supply for tree growth: $\mathrm{N}$ reserves in perennial parts of the tree and fertilizer $\mathrm{N}$. This makes it possible to accurately determine the contribution of reserve $\mathrm{N}$ to new growth (spur leaves, shoot leaves, shoots, and fruit) and the entire tree throughout the growing season if all the current season's $\mathrm{N}$ is provided in the form of ${ }^{15} \mathrm{~N}$-labeled fertilizer, and as such, the $\mathrm{N}$ demand-supply relationship can be quantified. In a previous experiment with 'Gala'/'M.26' trees in sand culture, we looked at the effect of $\mathrm{N}$ supply on the source-sink relationship and fruit size, and determined an optimal level of nutrient supply for these trees (Xia et al., 2009). In this study, we took the approach of sequential excavation of whole trees grown in sand culture, combined with labeling the current season's $\mathrm{N}$ supply with ${ }^{15} \mathrm{~N}$ over an entire growing season to determine the magnitude and seasonal patterns of all macroand micronutrients for the whole tree and individual organs, and the contribution of reserve $\mathrm{N}$ and current season's $\mathrm{N}$ uptake to tree $\mathrm{N}$ economy.

\section{Materials and Methods}

Plant Culture and nutrient supply. Six-year-old 'Gala'/ 'M.26' apple trees were grown in 55-L plastic containers in acid-washed sand $(\mathrm{pH} 6.2)$ at a spacing of $1.07 \times 3.35 \mathrm{~m}$ (equivalent to 2790 trees/ha) in east-west rows at Cornell Orchards in Ithaca, NY (lat. $42^{\circ} 26^{\prime} \mathrm{N}$, long. $76^{\circ} 29^{\prime} \mathrm{W}$, elevation $500 \mathrm{~m}$ ). They were trained in tall spindles and were about $3.6 \mathrm{~m}$ tall. These trees had been fertigated with $20 \mathrm{~N}-4.4 \mathrm{P}-16.6 \mathrm{~K}$ water-soluble fertilizer with micronutrients (Plantex ${ }^{\circledR}$ 20-10-20; Plantex Corp., Brampton, ON, Canada) and had produced regular crops over the previous 3 years. Before budbreak in 2006, the sand in all containers was washed several times with water to minimize residual $\mathrm{N}$ and other nutrients from previous years. Nutrient supply to the trees during the growing season of 2006 was based on a previous study (Xia et al., 2009). All the trees were fertigated with $4 \mathrm{~L}$ of $15.0 \mathrm{~mm} \mathrm{~N}$ from ${ }^{15} \mathrm{~N}$-enriched $\mathrm{NH}_{4} \mathrm{NO}_{3}\left(1.0392 \%{ }^{15} \mathrm{~N}\right.$ abundance) balanced with all other nutrients in Hoagland's No. 2 solution (Hoagland and Arnon, 1950) twice per week from 2 May until 4 weeks before fruit harvest, except during active shoot growth when the trees were fertigated three times per week. Fertigation continued from 4 weeks before harvest until fruit harvest, but $\mathrm{N}$ was provided at half the concentration for the first 2 weeks and then was completely omitted from the fertigation solution during the 2 weeks immediately preceding fruit harvest. After fruit harvest, each tree was fertigated twice with 4 L of the Hoagland's solution at an $\mathrm{N}$ concentration of $15.0 \mathrm{~mm} \mathrm{~N}$ (22 Sept. and 2 Oct.). Each tree received a total $30 \mathrm{~g}$ of actual $\mathrm{N}$ during the entire growing season (equivalent to $83.7 \mathrm{~kg} \cdot \mathrm{ha}^{-1} \mathrm{~N}$ ). The crop load of all trees was adjusted to 8.2 fruit $/ \mathrm{cm}^{2}$ trunk crosssectional area (TCA) by hand-thinning at king fruit diameter of $10 \mathrm{~mm}$ (104 fruit per tree), and this crop load was maintained to fruit harvest. Irrigation was provided with two microjet emitters per tree and the trees were well-watered throughout the growing season. No foliar application of nutrients was made to these trees. All trees received standard disease and insect control throughout the growing season. A copper spray was put on at budbreak to protect the trees from fireblight. This spray made it difficult to accurately determine the accumulation patterns of total $\mathrm{Cu}$ in new growth and the whole tree during the early part of the season.

WhOLE TREE DESTRUCTIVE SAMPLING AND LEAF AREA MEASUREMENTS. At each of the seven key developmental stages throughout the annual growth cycle (budbreak, bloom, end of spur leaf growth, end of shoot growth, rapid fruit expansion period, fruit harvest, and after leaf fall), four trees were excavated and destructively sampled. Each tree was partitioned into spurs $(<5 \mathrm{~cm})$, shoots $(>5 \mathrm{~cm})$, fruit, lateral branches, central leader, rootstock shank aboveground, rootstock shank belowground, and roots. Leaves were separated from spurs and shoots, and their total leaf area was measured with a leaf area meter (LI-3000; LI-COR, Lincoln, NE) before drying. All the spurs and shoots (after leaf removal), and lateral branches were cut into 2- to 3-cm-long sections and dried. The central leader 
was cut into 3-cm-long sections first, and was then further cut into smaller pieces before drying. Rootstock shanks were sawed into 1-cm-thick sections first, and were then cut into smaller pieces with a pruning lopper. Roots were thoroughly washed, blotted dry, and then dried along with other tissues in a forcedair oven at $75^{\circ} \mathrm{C}$. For the bloom and end-of-spur-leaf-growth sampling, all the fruit/flowers on each tree were dried. At later sampling dates, a 30-fruit sample was taken from each tree to determine the percentage of dry weight of fruit, and the total dry weight of fruit per tree was calculated based on total fruit fresh weight and the percentage of dry weight. Each fruit was cut into pieces and dried in a forced-air oven. The dry weight of all samples was recorded after reaching constant weight. The total dry weight of each tree was the sum of the dry weight of each tissue type, including fruit. The net dry matter gain per tree from budbreak to fruit harvest was calculated as the difference between total tree dry weight at fruit harvest and at budbreak. Harvest index was calculated as the percentage of net dry matter gain from budbreak to fruit harvest that was partitioned into fruit.

SAMPle PREPARATION AND NUTRIENT ANALYSIS. After drying, each sample was ground in a Wiley mill (Thomas Scientific, Swedesboro, NJ) to pass through a $2-\mathrm{mm}$ screen, and then in a Foss Tecator Cyclotec Mill (Fisher Scientific, Pittsburgh) to pass through a $0.5-\mathrm{mm}$ screen. Tissue $\mathrm{N}$ concentration was determined with a nitrogen analyzer (FP-428; LECO, St. Joseph, MI) via combustion, and $\mathrm{P}, \mathrm{K}, \mathrm{Ca}, \mathrm{Mg}, \mathrm{S}, \mathrm{B}, \mathrm{Zn}, \mathrm{Cu}$, $\mathrm{Mn}$, and Fe concentrations were measured with an Accuris inductively coupled plasma emission spectrometer (Fison Instrument, Dearborn, MI). Atom $\%{ }^{15} \mathrm{~N}$ abundance of the tissue samples was measured by mass spectrometry at Isotope Services (Los Alamos, NM).

Total N, P, K, Ca, Mg, S, B, Zn, Cu, Mn, and Fe in each organ type, and the whole tree, were calculated based on concentration and dry weight data. The percentage of nitrogen derived from the labeled fertilizer (i.e., NDFF\%) was calculated as (tissue atom $\%{ }^{15} \mathrm{~N}-0.3663$ ) $\times 100 \% /$ (fertilizer atom $\left.\%{ }^{15} \mathrm{~N}-0.3663\right)$, where $0.3663 \%$ is the natural abundance of ${ }^{15} \mathrm{~N}$. The total amount of fertilizer $\mathrm{N}$ in each organ or the whole tree was calculated as total $\mathrm{N} \times \mathrm{NDFF}$. Because all the $\mathrm{N}$ was supplied as ${ }^{15} \mathrm{~N}$-enriched $\mathrm{NH}_{4} \mathrm{NO}_{3}$ in 2006, the difference between total $\mathrm{N}$ and fertilizer $\mathrm{N}$ was taken as reserve $\mathrm{N}$.

YIELD, FRUIT SIZE, AND FRUIT QUALITY MEASUREMENTS. Fruit number, fruit yield per tree, and average fruit weight were measured at fruit harvest on 13 Sept. 2006. Fruit firmness was measured from the two peeled sides of each fruit with a penetrometer (EPT-1-R; Lake City Technical Products, Kelowna, BC, Canada). Soluble solids concentration (\%) was measured from the expressed juice of the fruit used for firmness tests with a portable digital refractometer (ATA-60 PAL-1; Atago USA, Bellevue, WA).

\section{Results}

LEAF AREA DEVELOPMENT, FRUIT GROWTH, YIELD, AND QUALITY. Tree total leaf area developed slowly from budbreak to bloom, increased very rapidly from bloom to the end of shoot growth, and then remained unchanged till fruit harvest (Fig. 1A). Average fruit weight showed an expolinear pattern of growth: an exponential phase from bloom to the end of shoot growth followed by a linear increase to fruit harvest (Fig. 1B).

Fruit yield was $18.8 \pm 0.4 \mathrm{~kg}$ per tree (equivalent to 52.45 $\left.\mathrm{t} \cdot \mathrm{ha}^{-1}\right)$ with an average fruit weight of $181.6 \pm 3.5 \mathrm{~g}$. Fruit
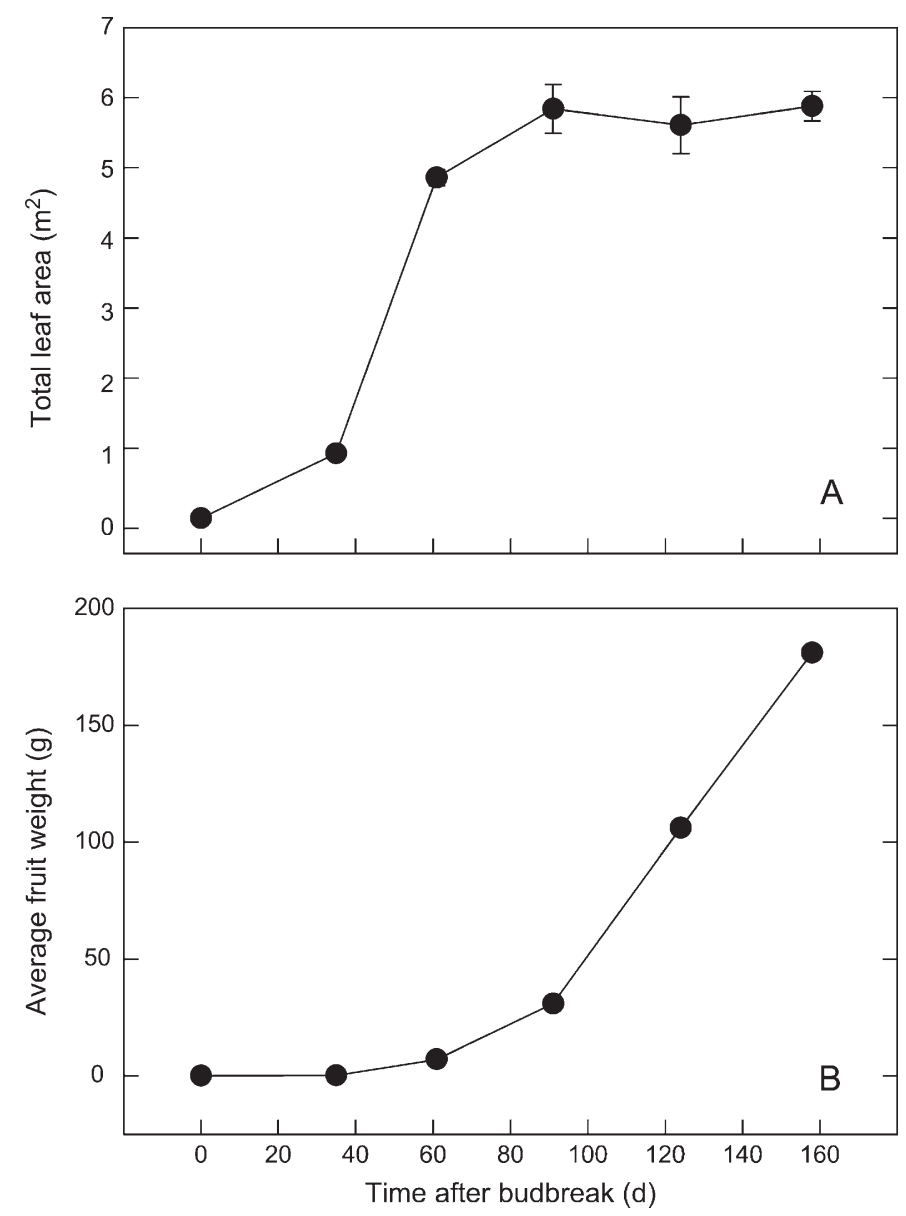

Fig. 1. Seasonal patterns of total leaf area per tree (A) and the average fruit fresh weight (B) of 6-year-old 'Gala'/'M.26' apple trees. The six points in each line correspond with budbreak, bloom, end of spur leaf growth, end of shoot growth, rapid fruit expansion period, and fruit harvest, respectively. Each point is mean \pm SE of four replicates.

soluble solids content was $14.5 \% \pm 0.25 \%$ and fruit firmness was $74.7 \pm 1.4 \mathrm{~N}$.

LEAF AND FRUIT NUTRIENT STATUS. The concentration of $\mathrm{N}, \mathrm{P}$, $\mathrm{K}, \mathrm{S}, \mathrm{Zn}$, and $\mathrm{Fe}$ in leaves and fruit decreased from bloom to fruit harvest, with concentrations being higher in leaves than in fruit from the end of shoot growth to fruit harvest (Fig. 2, A-C, $\mathrm{F}, \mathrm{H}$, and I). The concentration of $\mathrm{Ca}, \mathrm{Mg}$, and $\mathrm{Mn}$ in leaves decreased from bloom to the end of spur leaf growth, and then increased thereafter, whereas fruit $\mathrm{Ca}, \mathrm{Mg}$, and $\mathrm{Mn}$ concentrations decreased from bloom to fruit harvest (Fig. 2, D, E, and $\mathrm{J})$. The B concentration was higher in fruit than in leaves at bloom, but both had similar B concentrations from the end of spur leaf growth to fruit harvest (Fig. 2G).

Leaf samples taken at the regular time recommended for nutrient analysis (90 d after bloom), and fruit samples taken at harvest, showed that leaf and fruit nutrient status were in the satisfactory range for this cultivar (Table 1).

Dry MATTER ACCUMUlation AND PARTITIONing. Total dry matter of the tree showed an expolinear increase from budbreak to fruit harvest, with a net gain of $4.3 \mathrm{~kg}$ (Fig. 3A). Total dry matter of shoots and leaves increased rapidly from bloom to the end of shoot growth, and then remained unchanged till fruit harvest (Fig. 3B). Total dry matter of fruit increased exponentially from bloom to the end of shoot growth, and then in a linear fashion till 

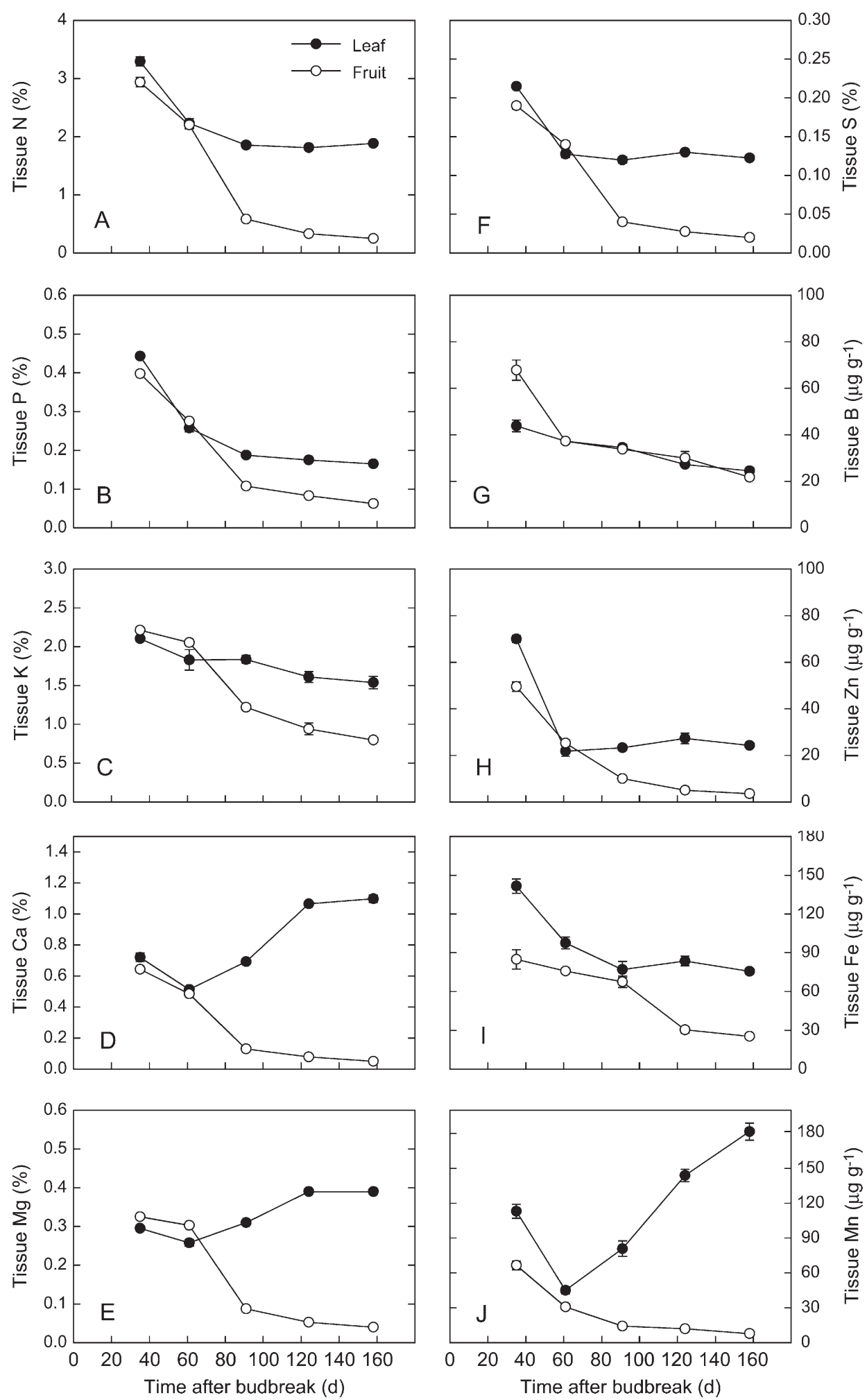

Fig. 2. The concentration of nitrogen (A), phosphorus (B), potassium $(\mathbf{C})$, calcium $(\mathbf{D})$, magnesium $(\mathbf{E})$, sulfur $(\mathbf{F})$, boron $(\mathbf{G})$, zinc $(\mathbf{H})$, iron $(\mathbf{I})$, and manganese $(\mathbf{J})$ in leaves and fruit of 6-year-old 'Gala'/'M.26' apple trees from bloom to fruit harvest. The five points in each line correspond with bloom, end of spur leaf growth, end of shoot growth, rapid fruit expansion period, and fruit harvest, respectively. Each point is mean \pm SE of four replicates. the dry matter of roots between budbreak and fruit harvest (Fig. 3D).

Of the net dry matter gain in the whole tree from budbreak to harvest, $72.2 \%$ was partitioned to fruit and $17.3 \%$ to shoots and leaves, with the rest $(10.5 \%)$ found in woody perennial parts (lateral branches, central leader, rootstock shank, and roots).

ACCUMUlation OF NUTRIENTS IN THE WHOLE TREe. Total tree $\mathrm{N}$ increased very rapidly from bloom to the end of shoot growth, and then continued to increase, but at a slower rate to fruit harvest (Fig. 4A). Total $\mathrm{P}, \mathrm{K}, \mathrm{Ca}, \mathrm{Mg}, \mathrm{S}$, and $\mathrm{B}$ in the tree increased slightly from budbreak to bloom and then in a near linear manner from bloom to fruit harvest, although accumulation of $\mathrm{Ca}, \mathrm{Mg}$, and $\mathrm{B}$ slowed starting from 1 month before harvest (Fig. 4, B-G). Total $\mathrm{Zn}$ and total $\mathrm{Mn}$ in the tree showed a gradual increase from budbreak to the end of spur leaf growth, and then a rapid increase until 1 month before fruit harvest, followed by a slow increase to fruit harvest (Fig. 4, H and $\mathrm{J}$ ). Total $\mathrm{Fe}$ in the tree increased rapidly from bloom to the end of shoot growth, followed by a slower increase till fruit harvest (Fig. 4I).

The net gains of total N, P, K, Ca, $\mathrm{Mg}$, and $\mathrm{S}$ from budbreak to fruit harvest were $19.8,3.3,36.0,14.2$, 4.4 , and $1.6 \mathrm{~g} /$ tree, respectively; and those for B, Zn, $\mathrm{Cu}, \mathrm{Mn}$, and Fe were 93.6, 60.9, 46.5, 184.8, and 148.7 $\mathrm{mg} /$ tree, respectively (Table 1 ).

The total amount of each nutrient in the whole tree after leaf fall was higher than that just before budbreak (Table 1).

ACCUMUlation OF NUTRIENTS IN NEW GROWTH (FRUIT, SHOOTS, AND LEAVES). Because fruit and shoots and leaves are the most dynamic parts of the tree, determining their nutrient accumulation patterns may help us understand their differential requirements for nutrients.

Total $\mathrm{N}$ in shoots and leaves followed the same pattern as dry matter (Fig. 5A). It increased slowly from budbreak to bloom, very rapidly from bloom to the end of shoot growth, and then remained unchanged until fruit harvest. In

fruit harvest (Fig. 3B). Dry weight of lateral branches, central leader, and rootstock shank showed little change from budbreak to the end of spur leaf growth, and then increased gradually to fruit harvest (Fig. 3C). No significant increase was observed in contrast, total $\mathrm{N}$ in fruit increased gradually from bloom to the end of shoot growth, and then increased rapidly until fruit harvest. The increase of total $\mathrm{N}$ in fruit from the end of shoot growth to fruit harvest made up $65.4 \%$ of fruit $\mathrm{N}$ accumulation, 


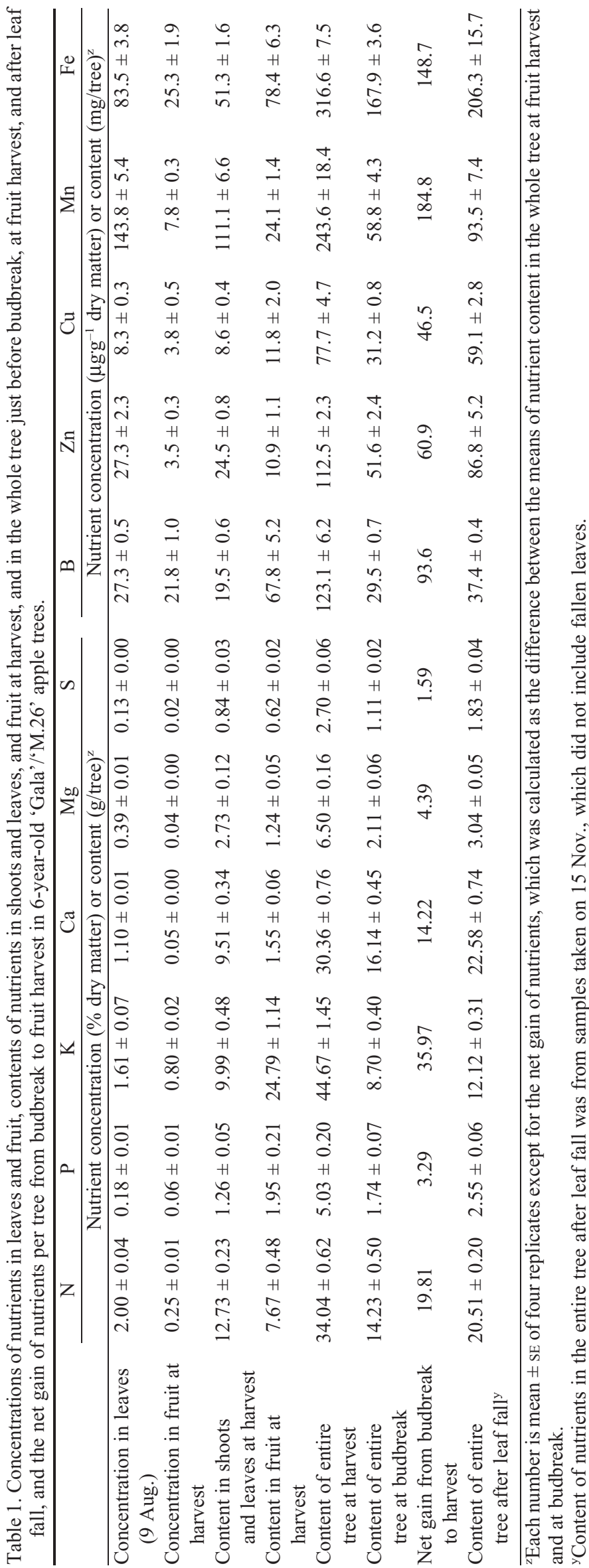
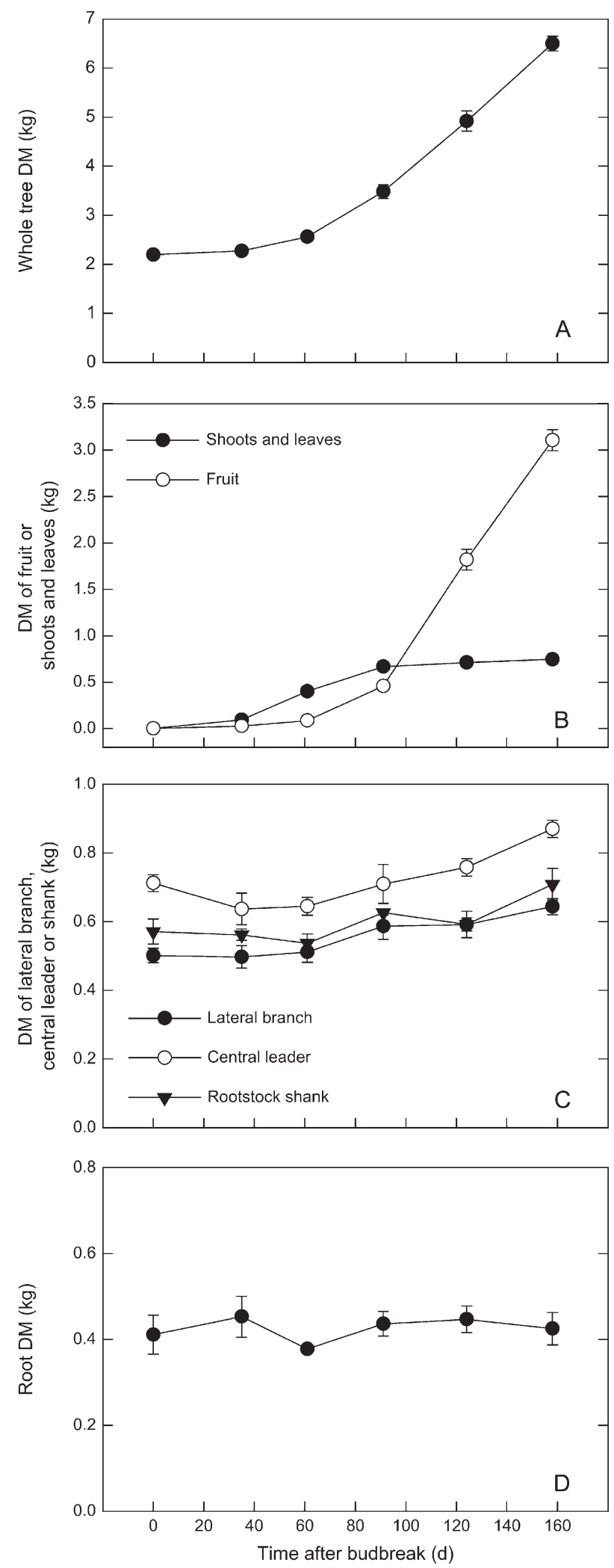

Fig. 3. Dry matter (DM) accumulation in the whole tree (A), fruit or shoots and leaves (B), lateral branches, central leader or rootstock shank (C), and roots (D) of 6-year-old 'Gala'/'M.26' apple trees from budbreak to fruit harvest. The six points in each line correspond with budbreak, bloom, end of spur leaf growth, end of shoot growth, rapid fruit expansion period, and fruit harvest, respectively. Each point is mean $\pm \mathrm{SE}$ of four replicates. 

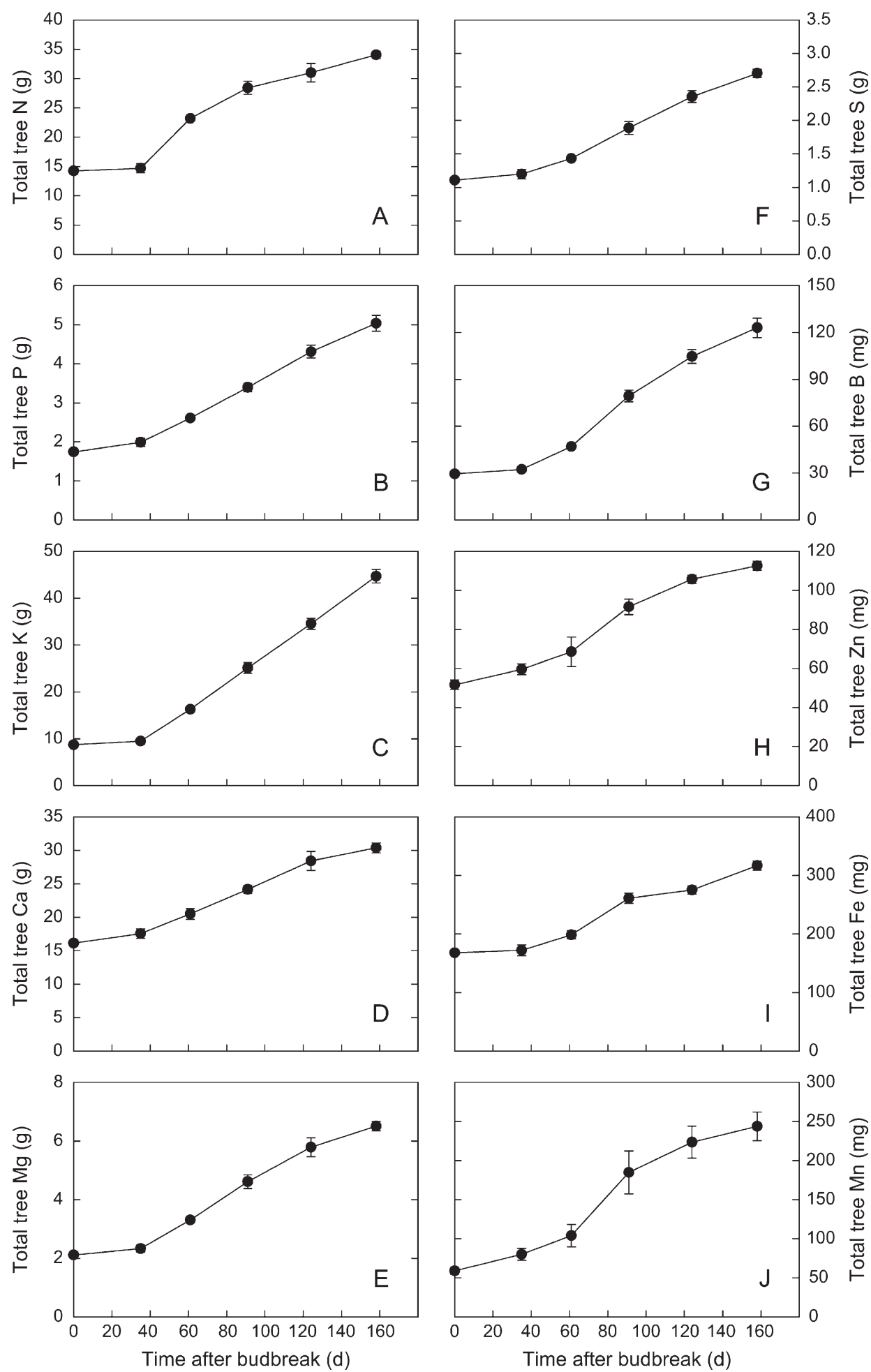

Fig. 4. Total accumulation of nitrogen (A), phosphorus (B), potassium (C), calcium (D), magnesium (E), sulfur $(\mathbf{F})$, boron $(\mathbf{G})$, zinc $(\mathbf{H})$, iron $(\mathbf{I})$, and manganese $(\mathbf{J})$ in 6-year-old 'Gala'/'M.26' apple trees from budbreak to fruit harvest. The six points in each line correspond with budbreak, bloom, end of spur leaf growth, end of shoot growth, rapid fruit expansion period, and fruit harvest, respectively. Each point is mean \pm SE of four replicates.

and accounted for all of the increase in total $\mathrm{N}$ in the new growth because the total $\mathrm{N}$ in shoots and leaves did not change during this period. At fruit harvest, total $\mathrm{N}$ in fruit accounted for $37.6 \%$ of $\mathrm{N}$ in new growth. Total $\mathrm{N}$ in new growth showed almost the same pattern as total $\mathrm{N}$ in the whole tree (Fig. 4A), and total $\mathrm{N}$ in new growth at fruit harvest accounted for $100 \%$ of net $\mathrm{N}$ accumulation in the whole tree from budbreak to fruit harvest. The accumulation patterns of total $\mathrm{S}$ in shoots and leaves and fruit were similar to those for total N (Fig. 5F). At fruit harvest, total $\mathrm{S}$ in fruit accounted for $42.6 \%$ of $\mathrm{S}$ in new growth, and total $\mathrm{S}$ in new growth accounted for $91.8 \%$ of its net gain in the whole tree from budbreak to fruit harvest.

Total P, K, B, and Fe in shoots and leaves increased very rapidly from bloom to the end of shoot growth and then remained unchanged till fruit harvest (Fig. 5, B, C, G, and I). In contrast, total $\mathrm{P}, \mathrm{K}, \mathrm{B}$, and $\mathrm{Fe}$ in fruit increased gradually from budbreak to the end of shoot growth, and then rapidly in a linear fashion till fruit harvest. The increase of $\mathrm{P}, \mathrm{K}, \mathrm{B}$, and $\mathrm{Fe}$ in fruit from the end of shoot growth to fruit harvest made up $74.9 \%, 77.4 \%, 77.2 \%$, and $61.0 \%$ of their total amount at fruit harvest, respectively. Total $\mathrm{P}, \mathrm{K}, \mathrm{B}$, and $\mathrm{Fe}$ in fruit at fruit harvest accounted for $60.7 \%, 71.3 \%, 77.7 \%$, and $60.4 \%$ of their total amount in new growth, respectively. Total $\mathrm{P}, \mathrm{K}, \mathrm{B}$, and $\mathrm{Fe}$ in new growth showed a linear or near linear increase from bloom to fruit harvest. Total $\mathrm{P}, \mathrm{K}, \mathrm{B}$, and $\mathrm{Fe}$ in new growth at fruit harvest accounted for $97.6 \%, 96.7 \%, 93.3 \%$, and $87.2 \%$ of their net accumulation in the whole tree from budbreak to fruit harvest, respectively.

Total $\mathrm{Ca}$ and $\mathrm{Mn}$ in new growth showed a slight increase from budbreak to bloom, and then a very rapid increase from bloom to 1 month before harvest, followed by a slow increase to fruit harvest (Fig. 5, D and $\mathrm{J}$ ). Total $\mathrm{Ca}$ and $\mathrm{Mn}$ in shoots and leaves accounted for most of the total $\mathrm{Ca}$ and $\mathrm{Mn}$ in new growth. Total $\mathrm{Ca}$ and $\mathrm{Mn}$ in fruit increased throughout the entire fruit growth period, with $61.7 \%$ and $73.3 \%$ of their respective accumulation occurring from the end of shoot growth to fruit harvest. However, total $\mathrm{Ca}$ and $\mathrm{Mn}$ in fruit at harvest accounted for only $14.0 \%$ and $17.8 \%$ of the total $\mathrm{Ca}$ and $\mathrm{Mn}$ in new growth, respectively. At fruit harvest, total $\mathrm{Ca}$ and $\mathrm{Mn}$ in new growth accounted for $77.8 \%$ and $73.2 \%$ of their net accumulation in the whole tree from budbreak to fruit harvest, respectively.

Total $\mathrm{Mg}$ and total $\mathrm{Zn}$ in shoots and leaves increased rapidly from bloom to the end of shoot growth, and then increased 

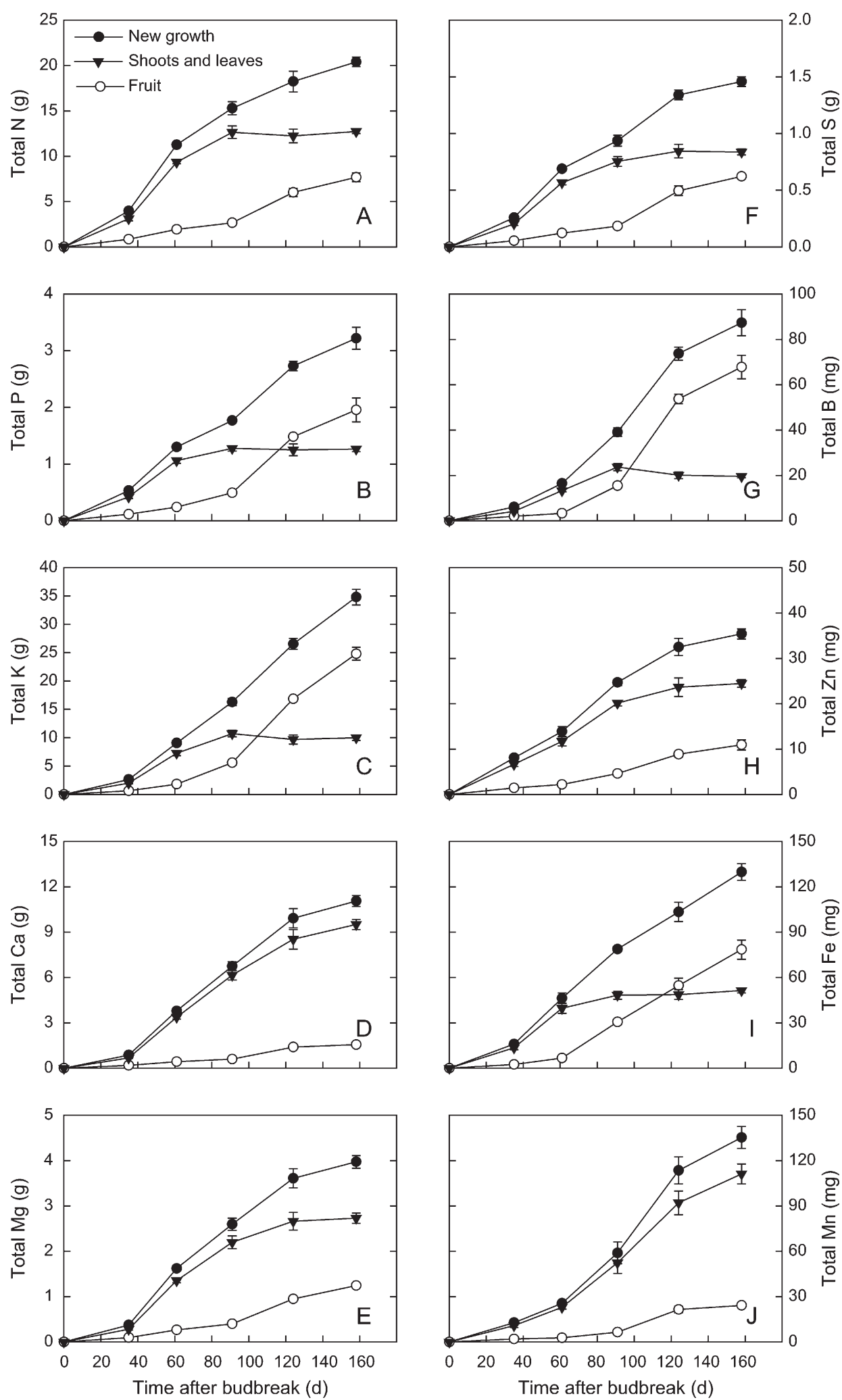

Fig. 5. Total accumulation of nitrogen (A), phosphorus (B), potassium (C), calcium (D), magnesium (E), sulfur $(\mathbf{F})$, boron $(\mathbf{G})$, zinc $(\mathbf{H})$, iron $(\mathbf{I})$, and manganese $(\mathbf{J})$ in shoots and leaves, fruit, and new growth (fruit plus shoots and leaves) of 6-year-old 'Gala'/'M.26' apple trees from budbreak to fruit harvest. The six points in each line correspond with budbreak, bloom, end of spur leaf growth, end of shoot growth, rapid fruit expansion period, and fruit harvest, respectively. Each point is mean $\pm \mathrm{SE}$ of four replicates. slowly till fruit harvest (Fig. 5, E and $\mathrm{H}$ ). In contrast, total $\mathrm{Mg}$ and total $\mathrm{Zn}$ in fruit increased slowly from bloom to the end of shoot growth and then rapidly from the end of shoot growth to fruit harvest, with $67.8 \%$ and $58.1 \%$ of the total accumulation taking place during the latter period. Total Mg and total $\mathrm{Zn}$ in fruit at fruit harvest accounted for $31.3 \%$ and $30.8 \%$ of the total $\mathrm{Mg}$ and total S in new growth, respectively. Total $\mathrm{Mg}$ and total $\mathrm{Zn}$ in new growth at fruit harvest accounted for $90.4 \%$ and $58.1 \%$ of their net accumulation in the whole tree from budbreak to fruit harvest, respectively.

CONTRIbution OF RESERVE $\mathbf{N}$ AND CURRENT UPTAKE OF $\mathbf{N}$ TO TREE $\mathbf{N}$ ECONOMY. There was a very limited $\mathrm{N}$ uptake from budbreak to bloom (Fig. 6A). However, total $\mathrm{N}$ uptake of the whole tree increased rapidly from bloom to the end of shoot growth, and then continued to increase at a slower rate, until fruit harvest. Total reserve $\mathrm{N}$ remained unchanged from budbreak to fruit harvest, except for a slight increase from bloom to the end of spur leaf growth. This slight increase was most likely due to uptake of the residual unlabelled $\mathrm{N}$ present in the sand, as total reserve $\mathrm{N}$ in a tree should not increase. At fruit harvest, reserve $\mathrm{N}$ and current uptake of fertilizer $\mathrm{N}$ each contributed about $50 \%$ to the total $\mathrm{N}$ in the whole tree.

Most of the $\mathrm{N}$ in new growth at bloom was supplied from reserve $\mathrm{N}$ remobilized from the perennial parts (including roots) of the tree (Fig. 6B). The amount of reserve $\mathrm{N}$ remobilized from perennial parts continued to increase until the end of spur leaf growth and then leveled off. The amount of fertilizer $\mathrm{N}$ in new growth increased very rapidly from bloom to the end of shoot growth, and then continued to increase at a slower rate, until fruit harvest. At fruit harvest, fertilizer N contributed about $55 \%$ to the total N in shoots and leaves with the balance supplied from reserve $\mathrm{N}$.

Total $\mathrm{N}$ in perennial parts decreased from budbreak to bloom at first, increased from bloom to the end of shoot growth, and then remained unchanged till fruit harvest (Fig. 6C). The amount of reserve $\mathrm{N}$ in 

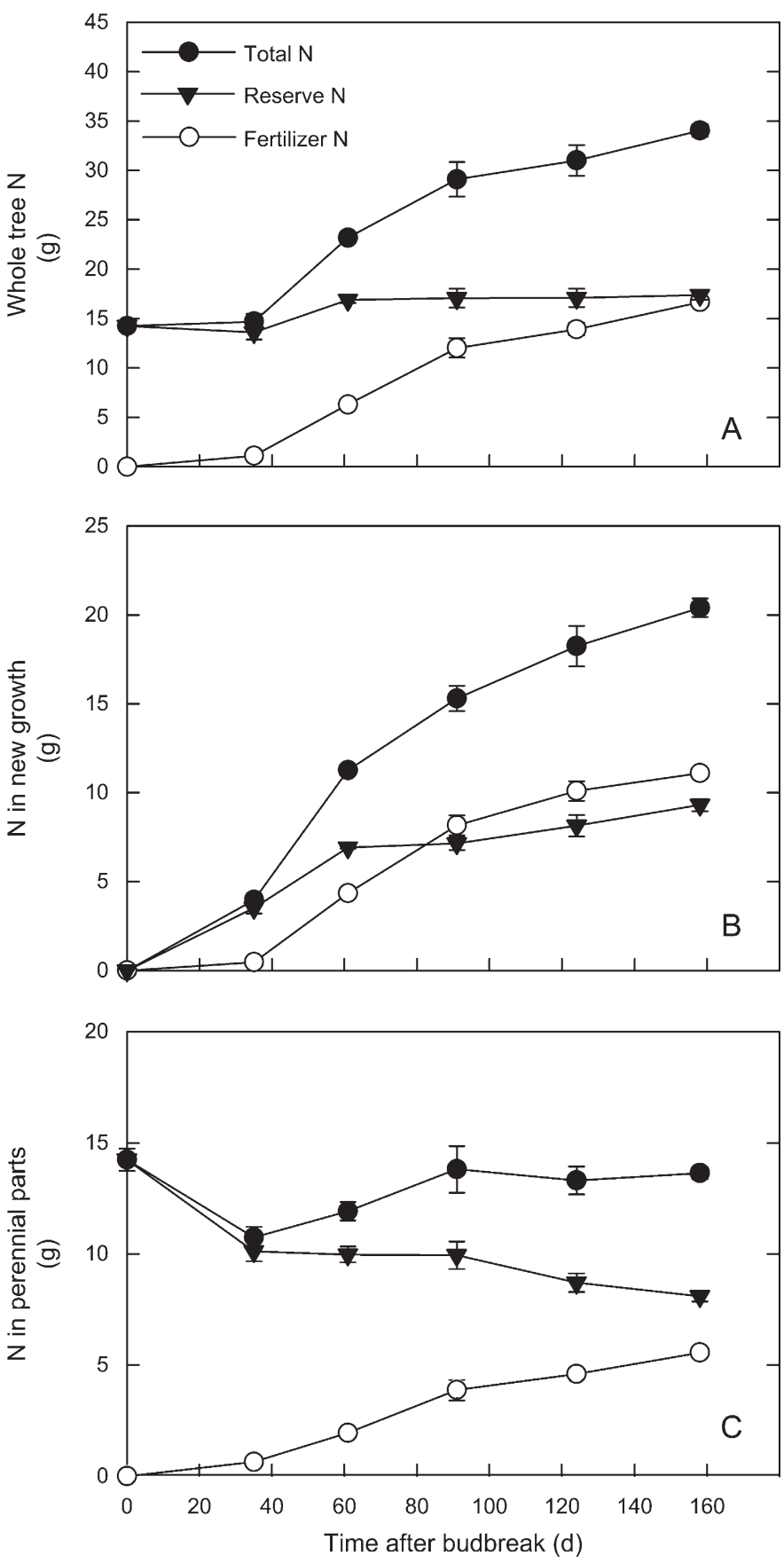

Fig. 6. Total $\mathrm{N}$, reserve $\mathrm{N}$, and fertilizer $\mathrm{N}$ in the whole tree (A), new growth (fruit plus shoots and leaves) (B), and perennial parts including roots (C) of 6-year-old 'Gala'/'M.26' apple trees from budbreak to fruit harvest. The six points in each line correspond with budbreak, bloom, end of spur leaf growth, end of shoot growth, rapid fruit expansion period, and fruit harvest, respectively. Each point is mean $\pm \mathrm{SE}$ of four replicates.

perennial parts decreased rapidly from budbreak to bloom, and then continued to decrease from bloom to fruit harvest. The amount of fertilizer $\mathrm{N}$ in perennial parts increased rapidly from bloom to the end of shoot growth, and then continued to increase at a slower rate, to fruit harvest. At fruit harvest, fertilizer $\mathrm{N}$ contributed about $40 \%$ to the total $\mathrm{N}$ in perennial parts.

The contribution of reserve $\mathrm{N}$ and fertilizer $\mathrm{N}$ to fruit and shoots and leaves showed differential patterns (Fig. 7). In shoots and leaves, reserve $\mathrm{N}$ remobilized from perennial parts
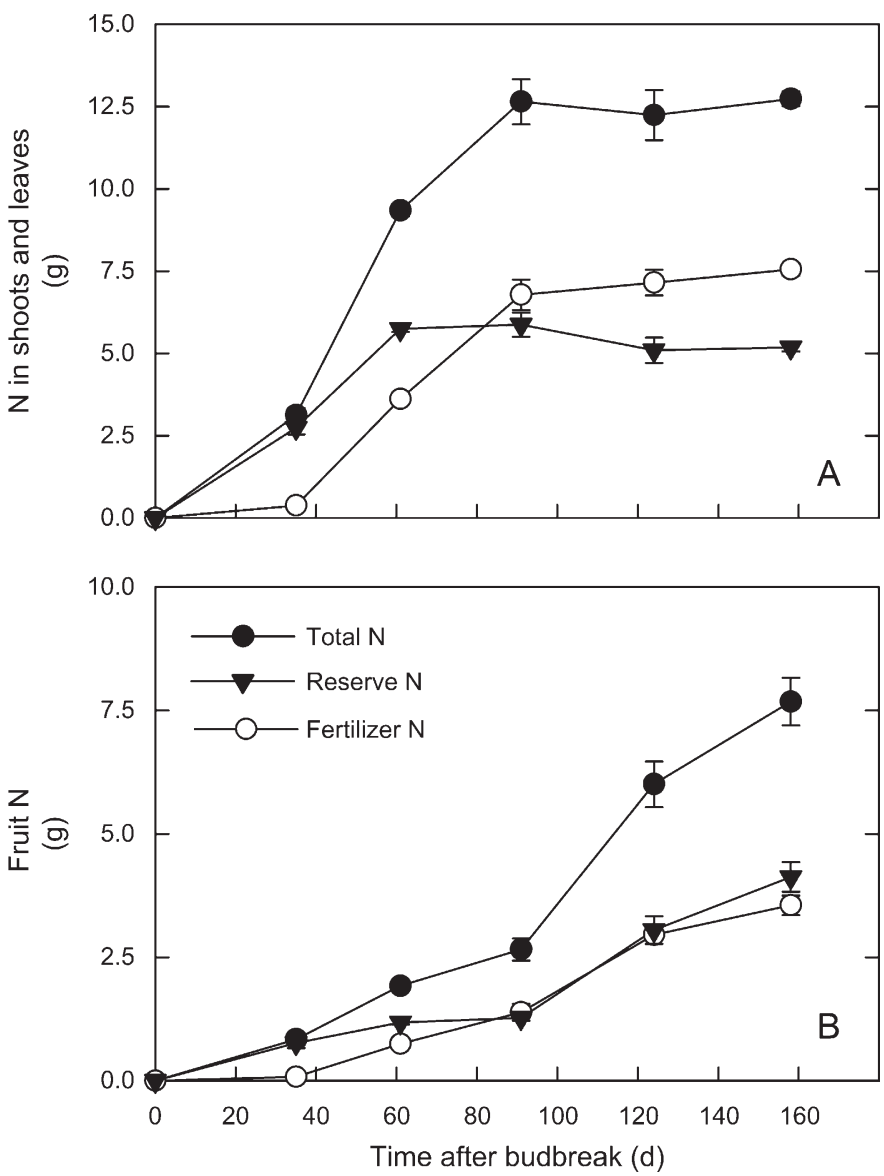

Fig. 7. Total $\mathrm{N}$ and the contribution from reserve $\mathrm{N}$ and fertilizer $\mathrm{N}$ in shoots and leaves (A) and fruit (B) of 6-year-old 'Gala'/'M.26' apple trees from budbreak to fruit harvest. The six points in each line correspond with budbreak, bloom, end of spur leaf growth, end of shoot growth, rapid fruit expansion period, and fruit harvest, respectively. Each point is mean $\pm \mathrm{SE}$ of four replicates.

increased rapidly from budbreak to the end of spur leaf growth and then remained unchanged until fruit harvest; the amount of fertilizer $\mathrm{N}$ increased rapidly from bloom to the end of shoot growth and then leveled off (Fig. 7A). In contrast, the amount of reserve $\mathrm{N}$ in fruit increased slowly from budbreak to the end of shoot growth, and then increased at a much higher rate until fruit harvest; the amount of fertilizer $\mathrm{N}$ increased slowly from bloom to the end of shoot growth and then increased at a higher rate to fruit harvest (Fig. 7B). At fruit harvest, fertilizer $\mathrm{N}$ and reserve $\mathrm{N}$ contributed $60 \%$ and $40 \%$ to the total $\mathrm{N}$ in shoots and leaves respectively, whereas they contributed about equal amounts to the total $\mathrm{N}$ in fruit.

\section{Discussion}

The seasonal patterns of nutrient concentrations in leaves and fruit observed in this study are in general agreement with those reported previously (Diamond et al., 1998; Fallahi et al., 1984a, 1984b; Rogers and Batjer, 1954; Rogers et al., 1953; Wilkinson and Perring, 1964; Wolk et al., 1998). The concentration of most nutrients in leaves decreased as the growing season progressed, with only that of $\mathrm{Ca}, \mathrm{Mg}$, and $\mathrm{Mn}$ showing an increase; the concentration of all nutrients in fruit decreased during fruit development (Fig. 2). In contrast, the total amount of each nutrient in shoots and leaves, fruit, and the whole tree 
increased (Figs. 4 and 5). This demonstrates clearly that changes in tissue concentrations cannot be used to infer changes in total amount of nutrients when the total biomass is changing at the same time, which makes sequential destructive sampling of the whole tree necessary in determining the magnitude and seasonal patterns of nutrient accumulation, as discussed by Weinbaum et al. (2001).

Because the trees used in this study had optimal nutrient levels in leaves and fruit (Table 1; Fig. 2) and they produced a high fruit yield (equivalent to $52.45 \mathrm{t} \cdot \mathrm{ha}^{-1}$ ) with good fruit size and quality, the observed accumulation of nutrients represents the nutrient requirements of these trees. The net accumulation of $\mathrm{N}, \mathrm{P}, \mathrm{K}, \mathrm{Ca}, \mathrm{Mg}$, and $\mathrm{S}$ in the whole tree from budbreak to fruit harvest was $19.8,3.3,36.0,14.2,4.4$, and $1.6 \mathrm{~g} /$ tree, respectively; and that for $\mathrm{B}, \mathrm{Zn}, \mathrm{Cu}, \mathrm{Mn}$, and $\mathrm{Fe}$ was 93.6, 60.9, 46.5, 184.8 , and $148.7 \mathrm{mg} /$ tree, respectively; which was equivalent to $55.24,9.21,100.44,39.62,12.28$, and 4.46 $\mathrm{kg} \cdot \mathrm{ha}^{-1}$ for $\mathrm{N}, \mathrm{P}, \mathrm{K}, \mathrm{Ca}, \mathrm{Mg}$, and $\mathrm{S}$, respectively; and 261.1, 169.9, 129.7, 515.6, and 414.9 g.ha ${ }^{-1}$ for B, $\mathrm{Zn}, \mathrm{Cu}, \mathrm{Mn}$, and Fe, respectively, at a tree density of 2790 trees/ha. This study, for the first time, has generated a comprehensive nutrient accumulation data set for 'Gala'/'M.26' trees trained in tall spindle. The net accumulation of N, Ca, and $\mathrm{Mg}$ by these 'Gala'/'M.26' trees is similar to that reported by Van Slyke et al. (1905) on standard 'Rhode Island Greening' and 'Baldwin' apple trees, but the amounts of $\mathrm{P}$ and $\mathrm{K}$ were much higher in our study. In contrast, the net accumulation of macronutrients obtained in this study was about $50 \%$ of the estimates for standard mature 'Delicious' apple trees except for $\mathrm{K}$ being at $71 \%$ and $\mathrm{Ca}$ being at 24\% (Batjer et al., 1952; Magness and Regeimbal, 1938). Because Haynes and Goh (1980) did not provide the annual uptake data for macronutrients in 'Golden Delicious' on 'Northern Spy' rootstocks, direct comparisons with our study cannot be made. Nevertheless, if we use the total amount of macronutrients present in leaves and fruit as an estimate of the annual net accumulation, our data on macronutrients are comparable to theirs, except that amounts of $\mathrm{K}$ and $\mathrm{Ca}$ were lower in our study. The apparently lower $\mathrm{K}$ accumulation in our study is due to the exceptionally high amount of $\mathrm{K}$ estimated in their fruit $\left(120 \mathrm{~kg} \cdot \mathrm{ha}^{-1}\right)$ at a fruit dry matter of $5950 \mathrm{~kg} \cdot \mathrm{ha}^{-1}$ [converted to $54 \mathrm{t} \cdot \mathrm{ha}^{-1}$ fresh weight using $11 \%$ dry weight based on their previous data (Palmer and Dryden, 2006)], which would translate into a fruit $\mathrm{K}$ concentration of over $2 \%$ of dry matter. Either the trees used were in luxury consumption of $\mathrm{K}$, or an error was made by the authors (Goh and Haynes, 1983; Haynes and Goh, 1980) in measuring or calculating the total amount of $\mathrm{K}$ in fruit. However, the former does not seem to be the case as leaf $\mathrm{K}$ concentration was only $1.2 \%$ at the end of the season. The lower amount of $\mathrm{Ca}$ in our study is most likely related to the fact that leaf $\mathrm{Ca}$ concentration was at the lower end of the satisfactory range. In terms of the amount of nutrients in the fruit at harvest (fruit nutrient removal), our data are very similar to those of Palmer and Dryden (2006) on 'Royal Gala', 'Fuji', and 'Braeburn', and Drahorad (1999) on several apple cultivars, but the amount of $\mathrm{N}$ in our 'Gala' fruit was lower than that obtained on 'Cox Orange Pippin' (Greenham, 1980; Palmer and Dryden, 2006), after the fruit yield was adjusted to the same level. It is interesting to note that the accumulation of nutrients in new growth (fruit plus shoots and leaves) accounted for over $90 \%$ of the net gain for total $\mathrm{N}, \mathrm{P}, \mathrm{K}, \mathrm{Mg}$, $\mathrm{S}$, and $\mathrm{B}$ in the entire tree and a large proportion of the net gain for $\mathrm{Ca}, \mathrm{Zn}, \mathrm{Mn}$, and $\mathrm{Fe}$ (ranging from $58.1 \%$ in $\mathrm{Zn}$ to $87.2 \%$ in
Fe) from budbreak to fruit harvest in this study. Therefore, future studies of this type might gain most of the information on tree nutrient needs by just focusing on new growth (fruit, shoots, and leaves).

Fruit and shoots and leaves have differential nutrient accumulation patterns (Fig. 5). Our data indicated that the most rapid accumulation of all nutrients in shoots and leaves took place during active shoot growth, from bloom to the end of shoot growth, and the accumulation pattern of most nutrients corresponded well with the accumulation of dry matter, with continued accumulation observed only in total $\mathrm{Ca}$ and $\mathrm{Mn}$ in shoots and leaves after the end of shoot growth. Nutrient accumulation in fruit largely followed its dry matter accumulation, and a large proportion of the nutrient accumulation (ranging from $58.1 \%$ in $\mathrm{Zn}$ to $77.4 \%$ in $\mathrm{K}$ ) occurred from the end of shoot growth to fruit harvest. The differential patterns of nutrient accumulation between fruit and shoots and leaves, and the similarity between dry matter accumulation and accumulation patterns of most nutrients within each organ (Figs. 3B and 5 ), indicate that nutrient accumulation is demand-driven. The linear increase in $\mathrm{P}$ and $\mathrm{K}$ in the whole tree, and in new growth from bloom to harvest (Figs. 4B-C and 5B-C) indicates a constant demand for both nutrients during this period. The demand by shoots and leaves before the end of shoot growth accounted for a larger proportion of the total demand for $\mathrm{P}$ and $\mathrm{K}$, whereas the demand by fruit from the end of shoot growth to fruit harvest made up nearly the entire demand for new growth and the whole tree. At fruit harvest, shoots and leaves had more $\mathrm{N}, \mathrm{Ca}, \mathrm{Mg}, \mathrm{S}, \mathrm{Zn}$, and $\mathrm{Mn}$, whereas fruit had more $\mathrm{P}, \mathrm{K}, \mathrm{B}$, and $\mathrm{Fe}$. It should be noted that $\mathrm{B}$ had the highest proportion (77.7\%) partitioned to fruit among all nutrients (Fig. 5G) and was the only nutrient that had a much higher concentration in fruit (flowers) than in leaves at bloom (Fig. 2G), which clearly indicates the importance of $\mathrm{B}$ to fruit growth and development.

Although the leaf $\mathrm{Ca}$ level of the trees used in this study was at the lower end of the satisfactory range, fruit had a good $\mathrm{Ca}$ level with a $\mathrm{K} / \mathrm{Ca}$ ratio of 16 (Table 1). Ca accumulation in 'Gala' fruit was found to continue throughout its entire growth period from bloom to harvest, with $61.7 \%$ of total accumulation occurring from the end of shoot growth to harvest in our study (Fig. 5D). This contrasts with some of the earlier studies suggesting that $\mathrm{Ca}$ accumulation primarily takes place in the first few weeks after bloom (Faust, 1989; Wilkinson, 1968). The lack of continued increase in fruit $\mathrm{Ca}$ content previously observed in New York (Faust, 1989) may have been related to drought conditions during the summer, as most orchards were not irrigated then. The continued accumulation of $\mathrm{Ca}$ throughout fruit growth observed in central Washington under irrigated conditions (Rogers and Batjer, 1954) is also consistent with the idea that soil moisture may play an important role in determining Ca accumulation patterns in apple fruit. Wilkinson (1968) observed that more $\mathrm{Ca}$ was accumulated during the cell expansion stage of fruit development in wet years or under irrigation than in dry years without irrigation. All the trees used in the current study were well-watered throughout the growing season, and this may have facilitated the uptake of $\mathrm{Ca}$ and its continued accumulation in fruit.

The use of ${ }^{15} \mathrm{~N}$-enriched $\mathrm{NH}_{4} \mathrm{NO}_{3}$ as the only source for current season's $\mathrm{N}$ supply allowed us to estimate the contribution of reserve $\mathrm{N}$ and current season's $\mathrm{N}$ uptake to tree $\mathrm{N}$ economy. At fruit harvest, reserve $\mathrm{N}$ and current season's $\mathrm{N}$ 
uptake each contributed about $50 \%$ to the total $\mathrm{N}$ in trees. This is similar to the results obtained on 4-year-old 'Elstar'/'Malling 9' ('M.9') apple trees (Neilsen et al., 2001), 6- and 7-year-old 'Comice'/'Provence' pear trees (Sanchez et al., 1991), and mature almond trees (Weinbaum et al., 1987) grown in the field. Shoots and leaves were the main sink for reserve $\mathrm{N}$ and fertilizer $\mathrm{N}$ before the end of shoot growth, whereas fruit became the main sink after the end of shoot growth (Fig. 7). The proportion of $\mathrm{N}$ present in fruit relative to that in shoots and leaves at harvest found in this study was similar to that previously reported on 4-year-old 'Elstar'/'M.9' trees (Neilsen et al., 2001). Most of the $\mathrm{N}$ demand by new growth at bloom was provided by reserve $\mathrm{N}$ that had been remobilized from perennial parts of the tree; even at the end of spur leaf growth, about two-thirds of the total $\mathrm{N}$ in the new growth was from reserve $\mathrm{N}$ (Fig. 6B). This is consistent with the finding on 3-year-old 'Elstar'/'M.9' apple trees by Neilsen et al. (1997). In addition to supporting the initial growth of spur leaves, shoot leaves, and fruit, remobilization of $\mathrm{N}$ also occurred during rapid fruit expansion from the end of shoot growth to fruit harvest, as the increase in reserve $\mathrm{N}$ used for fruit growth during this period corresponded well with a decrease in reserve $\mathrm{N}$ in woody perennial tissues (Figs. 6C and 7B). The drawdown of reserve $\mathrm{N}$ in woody perennial tissues coincided with the accumulation of current season's $\mathrm{N}$ in the tissues from the end of shoot growth to fruit harvest (Fig. 6C). The most rapid uptake of fertilizer $\mathrm{N}$ occurred from bloom to the end of shoot growth (Fig. 6A), which corresponded to the highest tree demand.

The expolinear increase in whole tree dry matter from budbreak to harvest (Fig. 3A) indicates that the canopy of these trees maintained their photosynthetic function all the way to harvest because any significant drop in whole canopy net carbon assimilation rate at the latter part of the growing season would have resulted in a slowdown of dry matter accumulation. The pattern of average fruit fresh weight (Fig. 1B) and total fruit dry matter increase (Fig. 3B) is consistent with the expolinear model of apple fruit growth proposed by Lakso et al. (1995) and indicates that carbon supply to fruit growth was adequate in our study. Indeed, the average fruit size of this experiment matches that reported in a previous experiment on 5-year-old 'Gala'/ 'M.26' trees at a leaf area to fruit ratio of $558 \mathrm{~cm}^{2}$ per fruit (Xia et al., 2009). The harvest index (72.2\%) obtained in our study is also similar to that found on 5-year-old 'Gala'/'M.26' trees (Xia et al., 2009), and those $(63 \%-77 \%)$ previously reported on dwarf apple trees (Avery, 1970; Forshey and Mackee, 1970; Heim et al., 1979; Lenz, 1986; Palmer, 1988; Palmer et al., 2002). The fact that no significant increase in root biomass was found from budbreak to fruit harvest, and that only about $10.5 \%$ of the net dry matter gain was partitioned into woody perennial tissues indicates that these dwarf apple trees are highly efficient in using available resources to support fruit growth. Under the nutrient supply regime used, it appears that these 'Gala'/'M.26' trees were able to sustain their growth and productivity because the trees retained from this experiment had adequate return bloom and very similar vegetative growth, yield, and fruit quality the following year.

This study was focused on determining the magnitude and seasonal patterns of nutrient accumulation of 'Gala'/'M.26' trees grown in sand culture. It should be emphasized that when developing fertilization programs in apple orchards, soil nutrient availability and tree nutrient status must be taken into consideration along with nutrient requirements. Considering that difference exists between sand-cultured trees and fieldgrown trees, extrapolation of the data generated in this study to field-grown trees in commercial orchards needs further testing. However, it is our belief that experiments using trees in sand culture, such as this one, complement those on field-grown trees, and both types of experimentation are necessary for understanding tree nutrient dynamics to optimize nutrient management practices in high-density apple orchards.

\section{Literature Cited}

Avery, D.J. 1970. Effects of fruiting on the growth of apple trees on four apple rootstock varieties. New Phytol. 69:19-30.

Batjer, L.P., B.L. Rogers, and A.H. Thompson. 1952. Fertilizer applications as related to nitrogen, phosphorus, potassium, calcium, and magnesium utilization by apple trees. Proc. Amer. Soc. Hort. Sci. 60:1-6.

Bould, C. 1966. Leaf analysis of deciduous fruits, p. 651-684. In: N.F. Childers (ed.). Temperate to tropical fruit nutrition. Horticultural Publications, Rutgers University, New Brunswick, NJ.

Diamond, D.H., E. Fallahi, B. Shafii, and R. Tripepi. 1998. Minimal nutrient flux in leaves of 'Fuji' apple trees on two rootstocks. Fruit Var. J. 52:236-248.

Drahorad, W. 1999. Modern guidelines on fruit tree nutrition. Compact Fruit Tree 32:66-72.

Fallahi, E., M.N. Westwood, M.H. Chaplin, and D.G. Richardson. 1984a. Influence of apple rootstocks and K and N fertilizers on apple leaf mineral composition and yield in a high density orchard. J. Plant Nutr. 7:1161-1177.

Fallahi, E., M.N. Westwood, M.H. Chaplin, and D.G. Richardson. 1984b. Effects of apple rootstocks and K and N fertilizers on seasonal apple fruit mineral composition in a high density orchard. J. Plant Nutr. 7:1179-1201.

Faust, M. 1989. Physiology of temperate zone fruit trees. Wiley, New York.

Forshey, C.G. and M.W. Mackee. 1970. Production efficiency of a large and a small 'McIntosh' apple tree. HortScience 5:164-165.

Goh, K.M. and R.J. Haynes. 1983. Nutrient inputs and outputs in a commercial orchard and their practical implications. N. Z. J. Expt. Agr. 11:59-62.

Greenham, D.W.P. 1980. Nutrient cycling: The estimation of orchard nutrient uptake. Acta Hort. 92:345-352.

Haynes, R.J. and K.M. Goh. 1980. Distribution and budget of nutrients in a commercial apple orchard. Plant Soil 56:445-457.

Heim, G., J.J. Landsberg, R.L. Watson, and P. Brain. 1979. Ecophysiology of apple trees: Dry matter production and partitioning by young Golden Delicious apple trees in France and England. J. Appl. Ecol. 16:179-194.

Hoagland, D.R. and D.I. Arnon. 1950. The water-culture method for growing plants without soil. California Agr. Expt. Sta. Circ. 347.

Khemira, H., T.L. Righetti, and A.N. Azarenko. 1998. Nitrogen partitioning in apple as affected by timing and tree growth habit. J. Hort. Sci. Biotechnol. 73:217-223.

Lakso, A.N., L. Corelli Grappadelli, J. Barnard, and M.C. Goffinet. 1995. An expolinear model of the growth pattern of the apple fruit. J. Hort. Sci. 70:389-394.

Lenz, F. 1986. Fruit effects on transpiration and dry matter production in apples, p. 101-104. In: A.N. Lakso and F. Lenz (eds.). The regulation of photosynthesis in fruit trees. New York State Agr. Expt. Sta. Spec. Publ., Geneva, NY.

Magness, J.R. and L.O. Regeimbal. 1938. The nitrogen requirements of the apple. Proc. Amer. Soc. Hort. Sci. 36:51-55.

Neilsen, D., P. Millard, G.H. Neilsen, and E.J. Hogue. 1997. Sources of $\mathrm{N}$ for leaf growth in a high-density apple (Malus domestica) orchard irrigated with ammonium nitrate solution. Tree Physiol. 17:733-739. Neilsen, D., P. Millard, G.H. Neilsen, and E.J. Hogue. 2001. Nitrogen uptake, efficiency of use, and partitioning for growth in young apple trees. J. Amer. Soc. Hort. Sci. 126:144-150. 
Palmer, J.W. 1988. Annual dry matter production and partitioning over the first 5 years of a bed system of Crispin/M.27 apple trees at four spacings. J. Appl. Ecol. 25:569-578.

Palmer, J.W. and G. Dryden. 2006. Fruit mineral removal rates from New Zealand apple (Malus domestica) orchards in the Nelson region. N. Z. J. Crop Hort. Sci. 34:27-32.

Palmer, J.W., J.N. Wünsche, M. Meland, and A. Hann. 2002. Annual dry matter production by three apple cultivars at four within-row spacings in New Zealand. J. Hort. Sci. Biotechnol. 77:712-717.

Rogers, B.L. and L.P. Batjer. 1954. Seasonal trends of six nutrient elements in the flesh of Winesap and Delicious apple fruits. Proc. Amer. Soc. Hort. Sci. 63:67-73.

Rogers, B.L., L.P. Batjer, and A.H. Thompson. 1953. Seasonal trend of several nutrient elements in Delicious apple leaves expressed on a per cent and unit area basis. Proc. Amer Soc. Hort. Sci. 61:1-5.

Rosecrance, R.C., R.S. Johnson, and S.A. Weinbaum. 1998. The effect of timing of post-harvest foliar urea sprays on nitrogen absorption and partitioning in peach and nectarine trees. J. Hort. Sci. Biotechnol. 73:856-861.

Sanchez, E.E., T.L. Righetti, D. Sugar, and P.B. Lombard. 1991. Recycling of nitrogen in field-grown 'Comice' pears. J. Hort. Sci. 66:479-486.

Sanchez, E.E., T.L. Righetti, D. Sugar, and P.B. Lombard. 1992. Effects of timing of nitrogen application on nitrogen partitioning between vegetative, reproductive, and structural components of mature 'Comice' pears. J. Hort. Sci. 67:51-58.

Van Slyke, L.L., O.M. Taylor, and W.H. Andrews. 1905. Plant food constituents used by bearing fruit trees. Bul. New York State Agr. Expt. Sta. 265:205-223.
Weinbaum, S.A. and C.V. Kessel. 1998. Quantitative estimates of uptake and internal cycling of ${ }^{14} \mathrm{~N}$-labeled fertilizer in mature walnut trees. Tree Physiol. 18:795-801.

Weinbaum, S.A., I. Klein, and T.T. Muraoka. 1987. Use of nitrogen isotopes and a light textured soil to assess annual contributions of nitrogen from soil and storage pools in mature almond trees. J. Amer. Soc. Hort. Sci. 112:526-529.

Weinbaum, S.A., I. Klein, F.E. Broadbent, W.C. Micke, and T.T. Muraoka. 1984. Effects of time of nitrogen application and soil texture on the availability of isotopically labeled fertilizer nitrogen to reproductive and vegetative tissue of mature almond trees. J. Amer. Soc. Hort. Sci. 109:339-343.

Weinbaum, S.A., P.H. Brown, R.C. Rosecrance, G.A. Picchioni, F.J.A. Niederholzer, F. Youseffi, and T.T. Muraoka. 2001. Necessity for whole tree excavations in determining patterns and magnitude of macronutrient uptake by mature deciduous fruit trees. Acta Hort. 564:41-49.

Wilkinson, B.G. 1968. Mineral composition of apples IX. Uptake of calcium by the fruit. J. Sci. Food Agr. 19:646-647.

Wilkinson, B.G. and M.A. Perring. 1964. Changes in the chemical composition of apples during development and near picking time. J. Sci. Food Agr. 15:146-152.

Wolk, W.D., O.L. Lau, G.H. Neilsen, and B.G. Drought. 1998. Factors and timing of sample collection for correlating storage potential of 'McIntosh', 'Spartan', and 'Golden Delicious' apples. J. Amer. Soc. Hort. Sci. 123:104-109.

Xia, G., L. Cheng, A.N. Lakso, and M.C. Goffinet. 2009. Effects of nitrogen supply on source-sink balance and fruit size of 'Gala' apple trees. J. Amer. Soc. Hort. Sci. 134:126-133. 